Turkish Online Journal of Qualitative Inquiry (TOJQI)

Volume 9, Issue 3, July 2018: 288-311 / Cilt 9, Sayı 3, Temmuz 2018: 288-311

DOI: $10.17569 /$ tojqi.407512

Research Article / Araştırma Makalesi

\title{
The Effects of a Mobile Assisted Vocabulary Learning Application on Vocabulary Learning
}

\author{
Serkan Gürkan ${ }^{1}$
}

\begin{abstract}
The improvements in technology have made it inevitable to use it in language learning process. Thus, the mobile assisted language learning (MALL) has gained importance recently. Besides, it is an undeniable fact that learning styles affect language learning process and use of MALL applications. Accordingly, this study aims to define students' views on the effects of a mobile assisted vocabulary learning (MAVL) application (VocaStyle), which was developed by the researcher, on their learning process and their learning styles' impact on their views. The study was in descriptive case study design. The data was gathered with semi-structured interview form. Ten participants were interviewed, five of which were aural learners and five of which were visual learners. The data was analyzed with thematic content analysis. The findings revealed that students found the MAVL application effective, motivating and useful. The findings also indicated that participants found video and graphic annotations more useful and their views changed depending on their learning styles.
\end{abstract}

Keywords: Mobile assisted language learning, EFL students, hypermedia annotation, vocabulary learning.

\footnotetext{
${ }^{1}$ Asst.Prof.Dr., Kocaeli University, Faculty of Education, Department of English Language Teaching, https://orcid.org/0000-0002-0996-9104
}

Received: 19.03.2018 Accepted: 31.07.2018 


\section{Mobil Destekli Kelime Öğrenimi Uygulamasının Kelime Öğrenimine Etkisi}

\section{$\ddot{\mathbf{O z}}$}

Son yıllarda yaşanan gelişmeler teknolojinin dil öğrenme sürecinde kullanılmasını kaçınılmaz hale getirmiştir. Buna bağlı olarak mobil destekli dil öğrenimi son yıllarda önem kazanmıştır. Mobil destekli dil öğreniminin yanı sıra, dil öğrenme stillerinin dil öğrenme sürecini ve mobil destekli dil öğrenimi uygulamalarının kullanımını etkilediği reddedilemez bir gerçektir. Bahsedilen bu bilgiler 1şığında tasarlanan bu çalışmanın amacı, öğrencilerin araştırmacı tarafından geliştirilen mobil destekli bir kelime öğrenimi uygulamasının (VocaStyle) ve dil öğrenme stillerinin öğrenme süreçlerine etkisi ile ilgili görüşlerini belirlemektir. Araştırma, nitel araştırma desenlerinden durum çalışması modelinde tasarlanmıştır. Araştırma verileri yarı yapılandırılmış görüşme formu ile toplanmıştır. Araştırma kapsamında çalışma grubunu oluşturan 10 katılımcı ile görüşmeler yapılmıştır. Bahsedilen 10 katılımcı 5'i işitsel, 5'i görsel öğreniciler olacak şekilde belirlenmiştir. Veri analizi sürecinde tematik içerik analizi yöntemi kullanılmıştır. Araştırma bulguları, öğrencilerin mobil destekli kelime uygulamasını yararlı, etkili ve güdüleyici bulduklarını ortaya çıkarmıştır. Araştırma kapsamında elde edilen başka bir bulgu ise öğrencilerin açıklayıcı eklere ilişkin görüşlerinin öğrenme stillerine göre değiştiğidir.

Anahtar Sözcükler: Mobil destekli dil öğrenimi, İngilizce ögrenicileri, hipermetin açıklayıcı ekler, kelime ögrenimi. 


\section{Introduction}

The use of technology in education in general and in English as a Second Language (ESL) and English as Foreign Language (EFL) learning has gained great popularity among educators and scholars as there are many educational institutions adopting new technologies in the conventional classroom environment that includes smart boards, projectors, audio systems and computers. Thus, mobile phones, tablets, computers and many diverse forms of information technologies are in use in today's language learning environments. The invention of wireless technology and the development in mobile technology world have gained much popularity in education field. Mobile devices include features of connectivity, social interactivity, context sensitivity, portability and individuality which personal computers may not do (Klopfer, Sheldon, Perry \& Chen, 2012). Mobile devices have transformed the way we learn and expanded our horizons by making learning portable, real-time, cooperative (Kukulska-Hulme, 2009; Wong \& Looi, 2011). In the light of these developments and the increasing attention Mobile-Assisted Language Learning (MALL), a great number of studies have been done to examine the possible effects of mobile technologies on language learning. One of these studies was conducted by Kukulska-Hulme (2010) and emphasized that mobile technologies provide learners with new tools to communicate and collaborate with each other by supplying lectures, tutorials and activities after the lesson, all of which reinforces learners during language learning process. Another study about mobile assisted language learning was conducted by Kim (2011). In this study, the effect of SMS text messaging on vocabulary learning was examined. Kim (2011) found out that students that used SMS text messaging after classes improved their vocabulary knowledge more by learning more words, and students gave positive feedback on using SMS text messaging for learning new vocabulary items. Kim (2011) emphasized that the reason for this improvement and positive feedback was interactivity in using new words. These studies show that MALL can be considered as beneficial for all learners, since almost every L2 learner has a mobile device today, and as a result of this, mobile devices may offer equal opportunities to L2 learners. Having these in mind, it is possible to say that mobile activities should be improved to cover four language skills, grammar, pronunciation and especially vocabulary learning, which is a "key to foreign language learning" (Masshady, Lotfi \& Noura, 2012). 
There have been a number of theories on mobile assisted language learning. This study relates to two of these theories which are Dual Coding Theory (DCT) (Paivio, 1990) and Generative Theory of Multimedia Learning (Mayer, 2001). While the former theory postulates the idea of pictorial-verbal system for knowledge construction in which a verbal system deals directly with language and a nonverbal (pictorial) system deals with non-linguistic objects, elements, and events; the latter theory puts forward that information, both verbal and visual, is accessed consecutively in short-term memory. Then the working memory comes into play as the place where the information is processed with both verbal and visual representations to get a holistic form leading to a more complete understanding of the information.

As well as the commonly accepted role of technology in language learning environments as an effective tool, the place of learning styles, on the other hand, is of crucial importance not only in just any form of learning but also in language learning. Learning styles are preferred ways of learning unconsciously that differ from one learner to other. They are students' approaches during learning something new or to cope up with a new problematic educational situation (Oxford, Ehrman, \& Lavine, 1991). They are also defined as differences among students in the use of various senses to comprehend, organize and retain experience (Reid, 1987). Thus, it is reasonable to comment that learners have different styles in getting new information in language learning and the effectiveness of teaching without taking into account of the existence of these different learning styles is questionable.

There have been many researchers (Dunn \& Dunn, 1978; Gregorc, 1979; Dunn, 1983, 1984; Kolb, 1984; Reid, 1987; Fleming, 2001; Duff ,2004) who conducted studies on learning styles and some learning styles models were suggested by these researchers. In this study, Reid's (1987) classification is used. Reid (1987) identified learning style preferences as the perceptual channels through which learners like to learn best. These channels are classified into auditory (learning by listening to audios, tapes and people), visual (learning by reading and studying charts, graphics and diagrams), kinesthetic (learning by physical participation), tactile (handson, learning by doing, e.g. doing lab experiments, building models), group (learning by studying with other learners in a group), and individual learning (studying in isolation).

Among many components of language learning as learning styles, vocabulary and reading also have attracted much attention of researchers lately. Vocabulary learning is an indispensable part of learning a new language (Nation, 2001). Much vocabulary might be learnt incidentally 
through reading (Nagy, 1997). Tassana-Ngam (2004) states that vocabulary is quite influential on reading skill. It might facilitate particularly comprehension of second language learners on a written text on the condition that the learners' vocabulary knowledge is lower or below the threshold minimum of approximately 3,000 words. Reading "large quantities of materials that is within learners' linguistic competence" (Grabe \& Stroller, 2002, p. 259), facilitates vocabulary learning by providing chances for inferring word meaning in context (Krashen, 2003).

There have been many studies revealing strong relationship between reading and vocabulary development (Gettys, Imhof \& Kautz, 2001; Cobb, 2007; Brown, Waring, Dankaewbua, 2008; Kweon \& Kim, 2008). Much of the vocabulary might be learned through reading incidentally, yet reading alone may not be sufficient all the time to extract necessary lexical information from the text. Mobile assisted language learning techniques might provide solutions to the problem of improving lexical knowledge not only by reading texts, but also using annotations. Use of annotations is believed to be an influential technique for vocabulary development. Annotations are regarded to be practical in reading in the second language; words or phrases that are not familiar with the learners' actual competence may be provided through annotations (Widdowson, 1984). The term annotation can be defined as the added extra virtual information to an object (Wither, DiVerdi, Höllerer, 2009). In vocabulary learning process, annotations can be in the form of text, graphic, audio or video, and they are added to a word in order to help learners to understand its meaning. Previous research on annotations yield controversial findings regarding the effectiveness of annotations and which annotation types are more effective (Wesche \& Paribakht, 1996; Laufer \& Hulstijn, 2001; Nation, 2001; Rott, Williams, and Cameron, 2002). Nation (2001), Wesche and Paribakht (1996) Rott, Williams, and Cameron (2002) examined the impact of annotations for incidental vocabulary learning for printed materials and revealed findings indicating vocabulary enhancement. On the other hand, Laufer and Hulstijn (2001) thought that using annotations was not an influential way of enhancing vocabulary learning. Most of the studies have been carried out through computerized conditions but there have been no studies concentrating on the relationship between the use of multimedia annotation types (text, pictures, audio, and video) and different learning styles and its effects on Mobile Assisted Vocabulary Learning (MAVL). Models for annotation technologies, their advantages, disadvantages and influence on readers and the characteristics of the annotations were reviewed in Wolfe's (2002) article. 


\section{Advantages of Annotations}

1.Developing understanding of source material

2.Quote for later review

3.Enable critical thinking

4.Comprehend and comment

5.Record intermediate and unselfconscious reaction to text

\section{Effects of Annotations}

1.Developing recall of emphasizing items

2.Affect perception of specific arguments

3.Decrease tendencies to unnecessarily summarize

All of information given above about advantages of annotations underlines the fact that use of technology in today's language learning environment can be thought as useful, and a mobile assisted language learning application including annotations could be beneficial for students with different learning styles. Thus, this study aims to examine students' views on the effects of a mobile assisted language learning application on their vocabulary learning process. Within the scope of this, the following sub-questions were sought answers:

1) What do students think about use of hypermedia annotations during vocabulary learning process?

2) What are the students' perceptions concerning the role of hypermedia annotations in learning vocabulary?

\section{Method}

\section{Research Design}

This study is in case study research design, which is a qualitative research method. In a case study, it is aimed to examine one or more situation with regard to time and context, and it should be examined within its boundaries (Creswell, 2007). This study is a descriptive case study in that it focuses on identifying students' views on the benefits of mobile assisted vocabulary learning application. 


\section{Context and Participants}

This study took place in 2016-2017 academic year in a state school in which Fatih Project is applied in Kocaeli, Turkey. The medium of instruction is English and students take 4 hours of English courses per week with a curriculum which was applied in all secondary schools in Turkey. The students have both paper-based coursebooks and electronic equivalents of their coursebook in their tablet computers which are delivered to all students in each school covered in Fatih Project. In selection of participants purposive sampling method was used. Participants of the study were 10 students who are enrolled in $10^{\text {th }}$ grade classes of a state elementary school in which multimedia learning was benefited. They shared similar educational backgrounds. To identify their learning styles, the researcher conducted Perceptual Learning Styles Questionnaire (Reid, 1987) to 49 students who benefited from multimedia assisted language learning. According to the results, five students were chosen among aural learners and five more chosen among visual learners.

For the requirement of this study an Android Application (VOCASTYLE) was developed by the researcher. The software was designed to supplement the English coursebook "Yes You Can" A.2.2 which is in use in the 10th grade of state schools in which multimedia learning is prevalent. It aims to support vocabulary learning of students. In this vein, target words from the reading texts were selected totally from the related coursebook. In this study a Prior knowledge test (VKS) Wesche and Paribakht (1996) was used as one week before the treatment in order to identify whether participants are familiar with any of the target words which were selected from the from reading texts in the English coursebook "Yes You Can" A.2.2 by their teachers at the state school. After the analysis of the results of VKS, the familiar words were extracted from the target word list and final version of 38 words of target word list was formed. Then these words were provided with annotations with the help of Vocastyle app. While learners come across to an unfamiliar vocabulary in a hypermedia reading text in Vocastyle, a number of different annotations (text, audio, graphic and video) were provided. Once they clicked on the target word, options appeared regarding which type of annotations they selected (Figure 1). According to their preferences they were exposed to the glosses as much as they want. 


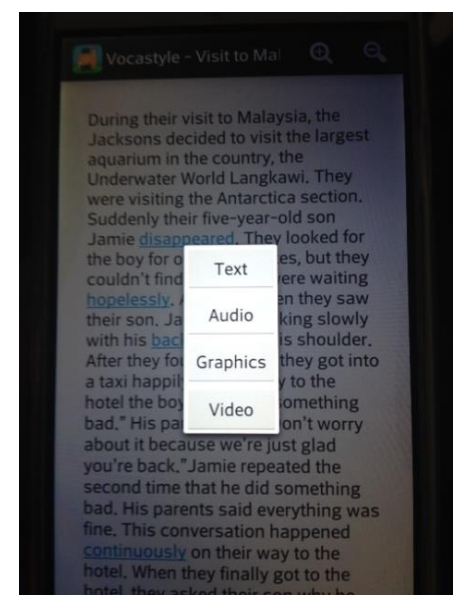

Figure 1. Annotation types for a specific vocabulary

Once they preferred textual gloss they saw the word class, English equivalent, an example sentence and a synonym of the target word (Figure 2).

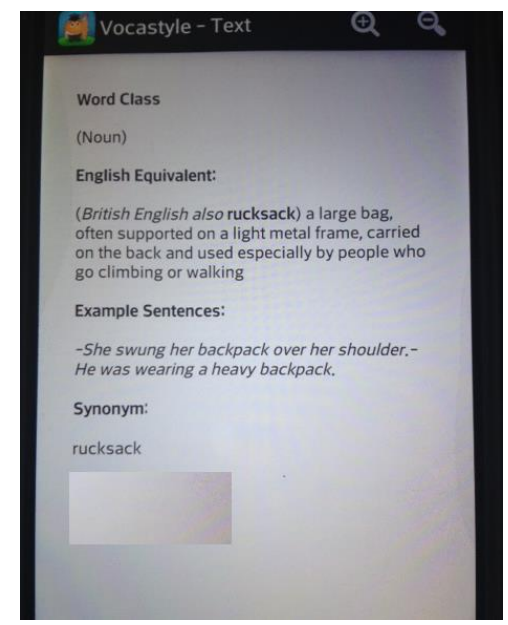

Figure 2. Sample text annotation for a specific vocabulary

Once they preferred audio, they could listen to aural input for the textual information from a native speaker. Students see a black screen so no figure was added for audio annotation here. When they preferred graphics they could see a picture related to the target word (Figure 3). 


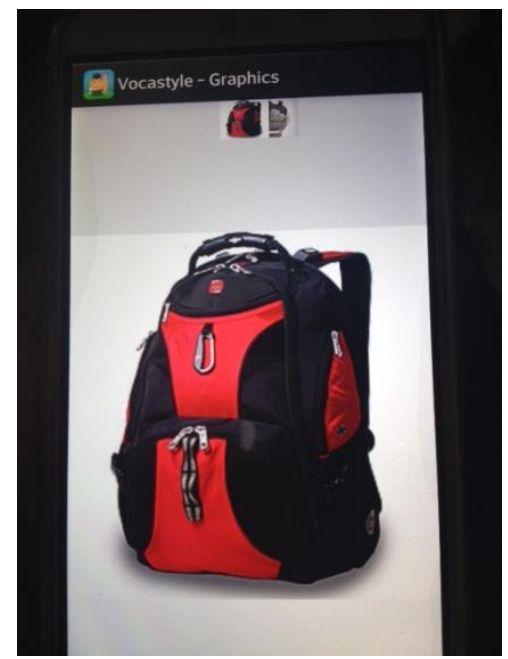

Figure 3. Sample graphic annotation for a specific vocabulary

Finally, If their preference was video, they could watch a short video clip of the target word (Figure 4). Then they were able to see their preferred annotation types as many times as they wish.

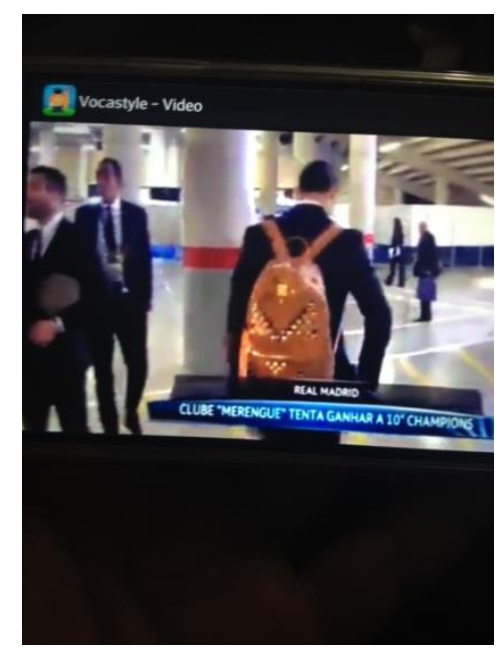

Figure 4. Sample video annotation for a specific vocabulary

\section{Data Collection Tool}

The data was collected through semi structured interview form. The questions are presented below:

1. What do you think about mobile assisted language learning?

a. Do you think VocaStyle help you comprehend the main text? If yes, please give examples from your experiences. 
2. How do you learn vocabulary better? By seeing or hearing it? Considering your choice, what type of annotations did you like most and find beneficial? Why?

3. Were the annotations useful? Which ones did you prefer the most? Why?

4. What do you suggest to improve Vocastyle?

Semi-structured interviews were conducted to have a better insight of participants about many components of the application and the process. Accordingly, interview questions were developed and, to ensure reliability and validity of the data collection instrument of the study, questions were sent to two experts from English Language Department and a Mobile application expert. These experts were asked to assess about the interview questions. After getting their positive feedback, the interview was piloted to 2 students from another school that had multimedia learning experience. These two students were asked to use Vocastyle software for a week and then they were asked about clarity of the questions, length of the interview, relations between the aim of the study and context of questions. Necessary corrections were done in the light of comments. Making sure that no big problems occurred both in using the application and in interviews, interviews were applied to real participants of the study.

Each interview lasted about one and a half hour. Digital voice recording was used by the researcher and data were transcribed verbatim. All personal identifiers were removed in order to protect anonymity of the participants. Thus, each participant was given a personal code (e.g., "S1V" refers to the student one who is a visual learner and S1A refers to the student who is auditory learner).

\section{Data Analysis}

A thematic analysis was conducted to the quantitative data in order to identify themes and subthemes. Firstly, researcher analysed all interviews to get familiar with the data. Then the researcher conducted an open coding approach. After this coding, the researcher asked two other experts for independent coding. At the end of the process of coding first transcript, the researcher and specialists came together to compare the codes and categories, and to agree on the themes. During this process, the interrelater reliability was calculated and found out as 0.85 , which is bigger than 0.70 and thus accepted as good harmony (Tavşanc1l \& Aslan,2001) With this meeting, codes and categories were developed, and themes were formed. The four main themes and sub-themes can be seen in Table 1 . 
Table 1

Main Themes and Sub-themes

\begin{tabular}{|c|c|}
\hline Main Themes & Sub-themes \\
\hline Multimedia Learning and & Text \\
\hline \multirow[t]{3}{*}{ Annotations } & Audio \\
\hline & Graphic \\
\hline & Video \\
\hline \multicolumn{2}{|l|}{ The navigation } \\
\hline \multicolumn{2}{|l|}{ The content } \\
\hline The motivation & \\
\hline
\end{tabular}

\section{Findings}

The themes and the sub-themes will be discussed in detail, including students' excerpts in this section.

\section{Multimedia Learning and Annotations}

The first theme emerged from students' answers was multimedia learning and annotations. Students evaluated each type of annotation, and it was seen that they emphasized each annotation had both positive and negative aspects. Each type of annotation will be discussed, including students' utterances.

\section{Text}

Some of the students found text annotations useful, because annotations helped them by giving meanings of the words and by providing example sentences. Some utterances of students are presented below:

"The Vocastyle made meanings of the words more understandable by using them in a sentence." (S2A)

"The Vocastyle helped me learn more words, because it had synonyms for each word." (S1V) 
"I didn't have to carry a dictionary with me through this mobile assisted language learning process, because the text annotations in the Vocastyle included the meanings of the unknown words." (S9V)

"I liked clicking on text annotations, because I like learning meanings of words in English and seeing example sentences. The Vocastyle provided me with this opportunity." (S6A)

However, the other students found text annotations difficult to understand and they emphasized they expected to see antonyms of the words, as well as synonyms. Some utterances of students are presented below:

"In text annotations, I expected to see antonyms of the words, as well as synonyms. Because I was curious about the antonyms when I saw there were synonyms. So, antonyms can be added to the Vocastyle." (S3V)

"For some words, the English meanings were difficult. There were unknown words in the meanings. I could give an example for it: In the English description of 'pigeon', there were a few unknown words, I couldn't understand them. The words in the descriptions could be easier." (S7V)

\section{Audio}

Most of the students who are auditory learners found audio annotations beneficial, because they liked hearing the pronunciation of the word from a native speaker. Some of the utterances of students are presented below:

"I know that, the spelling and the pronunciation of the words are different from each other in English. So, I try to read the word in the way that it is written if I don't hear the pronunciation of it. As a result of this, I learn both meaning and pronunciation of the word wrongly. Therefore, audio annotations helped me a lot." $(S 8 A)$

"I didn't know the pronunciation of the words, and the Vocastyle taught me a lot." $(S 3 V)$

"Without help from a teacher, I could learn the pronunciation of a word, thanks to Vocastyle!” (S10A)

"The audio annotations were what I like most about the Vocastyle. Hearing a native speaker pronouncing the words was an exciting experience for me." (S4A) 
"I liked audio annotations. It really helped me to learn pronunciations of the words. I remember how I was shocked when I heard the pronunciation of the word 'deteriorate'. I had seen that word before using Vocastyle, but I realized I pronounced it very wrongly when I listened to it by clicking on the programme." $(S 2 A)$

Even though most of the students found audio annotations useful, a student who is a visual learner emphasized it was beneficial but it wasn't helpful enough for learning the new word. The students' utterance can be seen below:

"Learning pronunciation of the new words was beneficial. But, I believe it didn't help me learn the new word. Other annotations were more useful for me. Audio just helped me learn correct pronunciation of the word. I believe I could learn the words without it, as well." (S5V)

\section{Graphic}

Like other annotations, some students found graphic annotations useful because of the fact that they visualized the words that helped students remember and learn the meaning of the word. Most of the students who found graphic annotations useful were visual learners. Some of the utterances of the students can be seen below:

"I like seeing things when learning. So I really like graphics.” (S1V)

"I really liked the graphics in the programme. They were fun. I remember the graphic for 'mouth-watering' included a cartoon character, Homer Simpson. I can still remember its facial impression, a 'watery' mouth! I believe I will never forget its meaning again." (S7V)

"I can learn by seeing. So, I found the pictures in the Vocastyle very useful for me to understand the meanings of the words. However I should mention that some pictures for abstract words didn't match with the meaning of the word. But, they were not much, maybe one or two." (S5V)

"Hypermedia annotations helped me learn new words. Especially the graphic annotations were very beneficial for me. I really like learning new words by looking at pictures related to them since secondary school. I used dictionaries with pictures since then, maybe I got used to learning in this way. And the Vocastyle gave me the chance to learn meanings of new words by looking at pictures related to them, which was fun for me. And there were at least 2 pictures for each word, which was great!" ( $S 9 \mathrm{~V})$ 
"Learning a new word with the help of different annotations was a great experience. When I had difficulty in understanding the text for a word, I could click on graphic or video annotations. I found the graphics most beneficial, because I know that I can learn better by looking at pictures about new words." (S5V)

As it can be seen in students' answers, graphic annotations were helpful for them. However, a student emphasized that some graphic annotations did not match with the meaning of some abstract words.

\section{Video}

The students' answers showed that the video annotations appealed both visual and auditory learners. Most of the students found video annotations helpful. Some utterances of students are presented below:

"The videos were very helpful. I really enjoyed watching them, and I could remember the meanings of the words easily thanks to videos." ( $\mathrm{S} 3 \mathrm{~V})$

"The videos drew my attention a lot. So I clicked on the words, watched the videos, and learned the meaning by having fun." (S4A)

"I could understand the content better by watching the videos." (S1V)

"Videos helped me have more clear images in my mind. For instance, I had difficulty in remembering the meaning of 'sightseeing tour' before watching the video. But now, I don't forget its meaning." (S5V)

"I think all annotations were useful for us. I can learn better by seeing or watching things. Because of this, I clicked on video annotations mostly. They were very helpful for me. They made meanings clear." (S8A)

"What I liked most about the Vocastyle was videos about words. I clicked on videos many times while learning. Especially for concrete words, the videos were very beneficial”. (S2A)

"Hypermedia annotations really helped me comprehend the main text. For example, the reading text 'Recycling' became more understandable for me with the help of annotations, especially the videos. As far as I remember, there was the word 'charity'. The video for this word was about Angelina Jolie, and I am a big fan of her. When I watched the video, I really enjoyed it and it helped me understand whole context better." (S10A)

"I think mobile assisted language learning should be used more frequently in our era. Most of us use smart phones, and all of us have tablets thanks to Fatih project. 
The Vocastyle was very beneficial for me. I feel that I really improved my vocabulary knowledge by using this software. It increased my motivation. If I had just read the text from the book, I would have got bored. However, I didn't. I really enjoyed clicking on annotations when I wanted to learn the meaning of words. Especially the videos were very useful in visualizing the concepts. They were catchy, made me learn and remember the meanings of the words." (S7V)

Although most students found the video annotations quite useful, two of the students emphasized the videos were sometimes a bit complicated and sometimes a bit longer. The utterances of these students can be seen below:

"Some videos could be clearer. For example, the video for 'magnificent' did not give the direct meaning. There was only a waterfall, at first I thought 'magnificent' means 'şelale'. With the help of other annotations, I could get the true meaning." $(S 9 V)$

"It was very fun for me to use the Vocastyle. I could say it was great to use it while learning new vocabulary, instead of just reading the text from the book, writing down the meanings of the words on my notebook. However, I could say that some videos, not all of them, could be shorter. I really liked 30 second-videos. But some of them were more than one and half minutes, which demotivated me. For example the video for 'patronage' was about one and half a minute, and after 40-45 seconds I lost my concentration." (S6A)

\section{The Navigation}

The second theme is the navigation of the Vocastyle, which can be considered as important in terms of user-friendliness of the software. Students emphasized that the Vocastyle is a userfriendly software. All students' utterances about the navigation are presented below:

"I really found mobile assisted learning beneficial. The software we used, Vocastyle, really helped me learn the vocabulary in the units better. It helped me learn in my own pace. I had the opportunity to click on the annotation I wanted, as much as I needed (...) I would like to add that the Vocastyle was clear and easy to use. $(S I V)$

The hypermedia annotations enabled me to understand the text better. The biggest role belongs to the Vocastyle's being student-friendly. It was always available for us, on our tablets, to go back and click on the annotations about the word we had difficulty in remembering. I didn't have to click annotations of one word, learn it, and then continue with the next one. I could start with the word I wanted and continue with the one I wanted. It really helped me." (S3V) 
"Thanks to Vocastyle, I liked mobile assisted learning process. Firstly, the Vocastyle was simple and clear. It was easy to use. I didn't have any complexity while using it. I could go back easily by clicking on my tablet's back button. Also the units were separated. Each unit and each text had a picture next to their names which made me remember it more easily. (S6A)I must say that I need more repetition than my classmates while I am learning a new word. Sometimes our teachers couldn't repeat as much as I need. In this aspect, the Vocastyle helped me. I could go back and forth, clicked on the word and its annotations whenever I needed. Also it was quite simple to use. Considering these, I took advantage of mobile assisted learning and I liked it." (S9V)

"I really liked mobile assisted learning (...) I wish mobile assisted learning was used for our other lessons, as well. Since I learned more by using the Vocastyle, I wish similar software was available for out other lessons. Honestly, I liked the Vocastyle, because it was easy to use. Just click on the unit's name, and then clicked on the text you wanted to study. There you are! If you click on the wrong unit or text, just click on back button." (S2A)

"Mobile assisted learning helped me a lot (...) I know I am a slow learner. Also, I can be lazy sometimes. With the Vocastyle, I could learn words at my own pace. I didn't have to hurry which made me motivated and feel ready for learning more." $(S 7 V)$

"When we talked with my classmates, most of us said we found hypermedia annotations beneficial. They really made us learn new words by understanding better. Using the software was very simple for us, and it made the process easier. Clicking on the annotation we wanted and going back to it when we needed was the best part of the Vocastyle." (S4A)

"Mobile assisted learning is very helpful. However, we should keep in mind that the software used is quite important. Sometimes I surf on the web and find some other online software for learning a subject in Science, for example. I came across some software which forced me to learn step by step. I mean, I had to learn one thing, then go on with the next one. But, I couldn't go back when I had to. But the Vocastyle wasn't like that. It enabled me to learn starting with the word I wanted, and -the best of it-I could go back and repeat whenever I needed." (S10A)

"Learning with mobile applications is great! The Vocastyle showed me this. It was a well-organised, clean, easy to use application. It didn't crash while I was using it, I could go back easily when I wanted, I didn't have to hurry since it didn't have any time constraints. All of these made me enjoy mobile assisted learning." (S8A)

\section{Content}

The third theme is about the Vocastyle's content. Students evaluated the software mainly in terms of language used and information provided. Some of the utterances are presented below: 
"Language of the Vocastyle was simple and easy to understand (...) Information was clear and easy to understand." (SIV)

"The reading texts were presented nicely and really organised." (S5V)

"I was able to understand the content because we can see a lot of examples there." (S6A)

"The Vocastyle was very useful and enough for basic understanding of the subject." (S10A)

\section{Motivation}

Students explained that the Vocastyle facilitated their language learning process. They emphasized that this software increased their motivation, which is an important aspect of language learning process. Some of the students' utterances are presented below:

"I found the software quite motivating (...) Mobile software is really practical way of learning unknown vocabulary. I could access it anytime." (S7V)

"The coursebook is quite boring but the software made it very interesting." (S2A)

"I love learning things from internet and Vocastyle helped me learn new words with pictures and videos." (S9V)

"I can't say I'm good at learning vocabulary but Vocastyle attracted my attention and made me concentrate more. It was more interesting than boring power point slides." $(\mathrm{S} 3 \mathrm{~V})$

"Vocastyle increased my motivation towards English lessons cause I learn better by seeing and it supplied various pictures and videos related with the pictures." (S10A)

"The software was working offline which enabled us full access anywhere, anytime even we don't have internet connection. I like using it this way because we don't have internet connection at home." (S5V)

According to students' answers, the software helped them during language learning process, since it was more enjoyable than listening to a teacher and they could access it without internet connection, which made it more useful and accessible. 


\section{Discussion, Conclusion and Implications}

Interview findings showed that students found video annotations and graphic annotations much more motivating and interesting than others. This finding is in line with many studies in literature either directly on multimedia learning or use of annotations in foreign language learning. Türk and Erçetin (2014) found that presenting verbal and visual information simultaneously is more influential and motivating. Ariew and Ercetin (2004) explored whether there is a link between reading comprehension and the use of different types of hypermedia annotations. Ultimately, data derived from questionnaires and interviews demonstrated that the participants' attitudes toward reading were positively affected by hypermedia reading. Hoven and Palalas (2011) concentrated on the mobile-assisted component of English for Specific Purposes course that focused on listening and speaking skills in a Canadian college. It was found out that student had positive attitudes towards using the mobile resources and displayed higher listening and speaking performances. Frohberg, Goth, and Schwabe (2009) classified 102 mobile projects on learning and noticed that most activities of mobile learning happened across diverse environments, and occurred in places such as classrooms and workplaces. Considering the instructional roles of mobile devices in educational environments, these devices have mostly been regarded, firstly, as stimulative and motivational tools rather than content-carrying digital tools. Findings obtained from interviews also showed that the nature of multimedia software made video, audio and graphic annotations much more advantageous than text annotation. Many participants remarked that watching the video or seeing a picture explaining the target word is more motivating, interesting and funnier than reading textual explanations corresponding to target word.

Interview data indicated that many students who have visual perceptual styles remarked that videos and graphics facilitated their learning more compared to auditory learners who claimed that audio and videos helped them more in learning the target words. This finding contradicts with Ross and Schulz (1999) who examined the interrelation between cognitive learning styles (concrete random, abstract random, concrete sequential and abstract sequential) and computerassisted instruction. They found that dominant learning styles of the participants did not cause a significant difference in interaction patterns of participants with CAI software. The researchers implicated that Computer-Assisted Instruction is effective to some extent but might not be suitable for all types of learners. 
The interviewees also remarked that multimedia annotations helped them in learning target vocabulary much. Many of them remarked that video, graphic and audio annotations were really helpful during the process. Some of them commented that text annotations were boring and they mostly did not preferred text annotations in the existence of videos, graphics and audios. With specific reference to text annotations some of the students remarked that text annotations were useful, because annotations helped them by giving meanings of the words and by providing example sentences. On the other hand, there were some other students who found text annotations difficult to understand and they stressed that they anticipated to see antonyms of the words, as well as synonyms. Thus, antonyms of target words might have been added to provide a better picture to learners and equivalents of the target words should have been checked over and over again. Some corrections or adaptations to equivalents to text annotations might contribute to efficiency of text annotations.

On the part of audio annotations, findings indicated that students who are auditory learners found audio annotations beneficial, because they liked hearing the pronunciation of the word from a native speaker and visual learners found it a little bit redundant as they tend to rely mostly on visual annotations. This finding is not surprising as this study gives an opportunity to learners to learn through their own learning style. Therefore, auditory leaners presumably would prefer audio annotations and visual learners would prefer visual annotations more.

From the perspective of graphic annotations, as well as the previous annotations, some students found graphic annotations useful because of the fact that they visualized the words that helped students remember and learn the meaning of the word. Most of the students who found graphic annotations useful were visual learners. On the other hand, a student emphasized that some graphic annotations did not match with the meaning of some abstract words. This finding should be approached cautiously and related target words and their graphic annotations should be checked. If there are some mismatches they should be replaced by correct ones. Even if there is only one student remarked this, there might be some misunderstandings especially in abstract words which might have led students to incorrect learnings. However, taken together, graphic annotations were found really effective and helpful in terms of learning new target vocabulary by making them more visual and memorable. Finally, for video annotations, findings indicated that they appealed both visual and auditory learners by using dual channel input simultaneously. Most of the students found video annotations helpful, there were also some student who favour 
for video annotations but who have some concerns about it. For example, some of the videos were much longer up to 40-45 seconds while most of them were in reasonable length and there were a few videos which might not be compatible enough with the target word it had intended to match. Even if those video(s) are not much in number (1-2), they might have affected the results. However, taken together most of the learners think these annotations were catchy, kept them motivated and made them more enthusiastic as well as making the target words more memorable.

The findings above are in line with Dual Code Theory (Paivio, 1990) and Generative Theory of Multimedia Learning Theory (Mayer, 2001). Generally, when language learners are offered both verbal and visual input via multimedia, they choose and arrange helpful information accordingly into different models. Thus, the relationships can be established to construct a kind of structure which is mental and meaningful. In fact, linguistic elements, specifically words, in verbal models offer discrete and linear information, but a holistic and nonlinear type of information is offered by pictures in other models. Therefore, learners can have better comprehension when they incorporate knowledge structures into the related models (Ariew, 2006). The findings above are also in congruence with the findings of the following studies. Chen and Chang (2011) explored the moderating effect of L2 English proficiency upon presentation mode and found that there was no moderating effect since student having dual mode scored performed better than the students who had access only to audio across proficiency levels. In another study, Xu (2010) examined the effect of L1, L2, and L1 + L2 annotations on L2 vocabulary learning and found that L1 annotations were more effective in enhancing L2 vocabulary learning than L2 and L1 + L2 annotations. In the same line, the study by Hulstijn, Hollander, and Greidanus (1996) lent support to the effectiveness of L1 annotations on enhancing L2 vocabulary learning.

In the light of the conclusions of the study there are a number of implications with respect to aspects multimedia assisted vocabulary learning, multimedia annotations and learning styles. Firstly, material developers should consider that in today's world where technology surrounds us from all aspects, technology, more precisely, multimedia should be integrated into EFL curricula. More specifically, in the light of the results of this study, multimedia annotated vocabulary teaching should be stressed. More coursebooks and supplementary materials should be designed and annotations should be embedded to related parts with great scrutiny. By doing this practitioners and designers should take into account that annotations should be appropriate 
to the target word. Apart from that the way they are presented, simultaneous or linear, and diverse combinations of annotations (text+picture, text+audio, etc.) should be given in accordance to learning styles of learners. However, as discussed above preparing multimedia annotations for every learning style is not an easy task. Therefore software designer and material developers should work hand in hand to prepare really efficient applications which enable diversity in different types of multimedia annotations for each learning style.

The present study has a number of limitations. Firstly, treatment lasted only 4 weeks due. Longer period of time allotted to treatment could have given different findings. Secondly, this study concentrated on only two perceptual learning styles, visual and auditory. Therefore the findings cannot be generalized to all learning styles. In addition, the treatment was limited only with 10th grade EFL learners. Treatment to different grades could have given different findings.

Finally a number of suggestions can be made for further research. Firstly, the content can be widened and a qualitative research design can be used to analyze the students' views on benefits of Mobile Assisted Language Learning. Secondly, another study might be conducted to examine the effect of different type of annotations on vocabulary learning. Third, a longitudinal study with longer period of use of the software might be carried out to see effects. 


\section{References}

Ariew, R. (2006). A template to generate hypertext and hypermedia reading materials: Its design and associated research findings. The Reading Matrix, 6(3), 195-209.

Ariew, R., \& Ercetin, G. (2004). Exploring the potential of hypermedia annotations for second language reading. Computer Assisted Language Learning Journal, 17(2), 237-259.

Baxter, P., \& Jack, S. (2008). Qualitative case study methodology: Study design and implementation for novice researchers. The Qualitative Report, 13(4), 544-559.

Brown, R., Waring, R., \& Donkaewbua, S. (2008). Incidental vocabulary acquisition from reading, reading-while-listening, and listening to stories. Reading in a Foreign Language, 20, 136-163.

Chen, I-J., \& Chang, C-C. (2011). Content presentation modes in mobile language listening tasks: English proficiency as a moderator. Computer Assisted Language Learning, 24(5), $451-470$.

Cobb, T. (2007). Computing the vocabulary demands of L2 reading. Language Learning \& Technology, 11, 3, 38-63. Retrieved from:

http://lit.msu.edu/vol11 num3/cobb/default.html.

Creswell, J. W. (2007). Qualitative inquiry and research design: Choosing among five approaches. California: Sage Publications.

Duff, A. (2004). Approaches to learning: The revised approaches to studying inventory. Active Learning in Higher Education, 5(1), 56-72.

Dunn, R., \& Dunn, K. (1978). Teaching students through their individual learning styles: A practical approach. Englewood Cliffs, NJ: Reston Book.

Dunn, R. (1983). Can Students Identify Their Own Learning Styles?. Educational leadership, 40(5), 60-62.

Dunn, R. (1984). Learning style: State of the science. Theory into Practice, 23(1), 10-19.

Fleming, N.D. (2001). Teaching and learning styles: VARK strategies. Christchurch, New Zeland: N.D. Fleming.

Frohberg, D., Goth, C., \& Schwabe, G. (2009). Mobile learning projects e a critical analysis of the state of the art. Journal of Computer Assisted Learning, 25, 307-331.

Gettys, S., Imhof, L. A., \& Kautz, J. O. (2001). Computer-assisted reading: The effect of glossing format on comprehension and vocabulary retention. Foreign Language Annals, 34, 91-106. doi:10.1111/j.1944-9720.2001.tb02815.x. 
Grabe, W., \& Stoller, F. (2002). The nature of reading abilities. Teaching and Researching Reading, 9-39.

Gregorc, A. F. (1979). Relating with style. Colombia, CT: Gregorc Associates.

Hoven, D., \& Palalas, A. (2011). (Re)conceptualizing design approaches for mobile language learning. CALICO Journal, 28(3), 699-720

Kim, H. S. (2011). Effects of SMS text messaging on vocabulary learning. Multimedia-Assisted Language Learning, 14(2), 159-180.

Klopfer, E., Sheldon, J., Perry, J., \& Chen, V. H. H. (2012). Ubiquitous games for learning (UbiqGames): Weatherlings, a worked example. Journal of Computer Assisted Learning, $28,465-476$.

Kolb, D. (1984). Experiential learning: Experience as the source of learning and development. Englewood Cliffs, NJ: Prentice-Hall.

Krashen, S. (2003). Explorations in language acquisition and use: The Taipei lectures. Portsmouth, NH: Heinemann, pp. 477-487.

Kukulska-Hulme, A. (2009). Will mobile learning change language learning?. ReCALL, 21(2), 157-165.

Kukulska-Hulme, A. (2010) Mobile learning as a catalyst for change, Open Learning: The Journal of Open, Distance and e-Learning, 25(3), 181-185.

Kweon, S.O., \& Kim, H.R. (2008). Beyond raw frequency: Incidental vocabulary acquisition in extensive reading. Reading in a Foreign Language, 20, 191-215.

Laufer, B., \& Hulstijn, J. H. (2001). Incidental vocabulary acquisition in a second language: the construct of task-induced involvement. Applied Linguistics, 22 (1), 1-26.

Mashhady, H., Lotfi, B., \& Noura, M. (2012). Word Type Effects on L2 Word Retrieval and Learning: Homonym versus Synonym Vocabulary Instruction. Iranian Journal of Applied Language Studies, 3(1), 97-118.

Mayer, R. E. (2001). Multimedia learning. New York, NY: Cambridge University Press.

Nagy, W. (1997). On the role of context in first- and second-language vocabulary learning. In N. Schmitt \& M. McCarthy (Eds.), Vocabulary: Description, acquisition and pedagogy (pp. 64-83). Cambridge: Cambridge University Press.

Nation, I. S. P. (2001). Learning vocabulary in another language. Cambridge, England: Cambridge University Press.

Oxford, R.L., Ehrman, M., \& Lavine, R. Z. (1991). Style wars: teacher-student style conflicts in the language classroom. In Magnan, S.S. (Ed.), Challenges in the 1990s for College Foreign Language Programs. Boston, MA: Heinle \& Heinle. 
Paivio, A. (1990). Mental representations: A dual coding approach. New York, NY: Oxford University Press.

Paribakht, T. S., \& Wesche, M. (1996). Enhancing vocabulary acquisition through reading: A hierarchy of text-related exercise types. The Canadian Modern Language Review, 52 (2), 155-178.

Reid, J. M. (1987). The learning style preferences of ESL students, TESOL Quarterly, 21(1), 87-111.

Ross, J., \& R. Schulz (1999). Can computer-aided instruction accommodate all learners equally?. British Journal of Educational Technology, 31(1), 5-24.

Rott, S., Williams, J., \& Cameron, R. (2002). The effect of multiple-choice L1 glosses and input-output cycles on lexical acquisition and retention. Language Teaching Research, 6, 183-222.

Tassana-ngam, I. (2004). The effect of vocabulary learning strategies training on Thai university students' word retention in the second language classroom. Unpublished $\mathrm{PhD}$ thesis. University of Essex, Colchester.

Tavşanc1l, E., \& Aslan, E. (2001). İçerik analizi ve uygulama örnekleri. İstanbul: Epsilon Yayıncilik.

Türk, E., \& Erçetin, G. (2014). Effects of interactive versus simultaneous display of multimedia glosses on L2 reading comprehension and incidental vocabulary learning. Computer Assisted Language Learning, 27(1), 1-25.

Wesche, M., \& Paribakht, T. S. (1996). Assessing Second Language Vocabulary Knowledge: Depth Versus Breadth. Canadian Modern Language Review, 53(1), 13-40.

Widdowson, H. G. (1984). Explorations in applied linguistics (Vol. 2). Oxford: Oxford University Press.

Wither, J., DiVerdi, S., \& Höllerer, T. (2009). Annotation in outdoor augmented reality. Computers \& Graphics, 33(6), 679-689.

Wolfe, J. L. (2002). Annotation technologies: A software and research review. Computers and Composition. 19, 471-497.

Wong, L. H., \& Looi, C. K. (2011). What seams do we remove in mobile assisted seamless learning? A critical review of the literature. Computers \& Education, 57(4), 2364-2381. 